\title{
Geographic, seasonal and ontogenetic variation in cadmium and mercury concentrations in squid (Cephalopoda: Teuthoidea) from UK waters
}

\author{
G.J. Pierce ${ }^{a}$, G. Stowasser ${ }^{a}$, L.C. Hastie ${ }^{a}$ and P. Bustamante ${ }^{\text {b, }}{ }^{*}$ \\ ${ }^{a}$ School of Biological Sciences [Zoology], University of Aberdeen, Tillydrone Avenue, Aberdeen AB24 2TZ, UK \\ ${ }^{\mathrm{b}}$ Centre de Recherche sur les Ecosystèmes Littoraux Anthropisés, UMR 6217 CNRS-IFREMER-Université de La \\ Rochelle, 22 Avenue Michel Crépeau, Université de La Rochelle, 17042 La Rochelle, France \\ *: Corresponding author : P. Bustamante, email address : paco.bustamante@univ-Ir.fr
}

\begin{abstract}
:
Cadmium (Cd) and mercury $(\mathrm{Hg})$ levels were measured in the tissue samples of two loliginid (Alloteuthis sp. and Loligo forbesi) and two ommastrephid (Todarodes sagittatus and Todaropsis eblanae) squid species collected from research cruise and fishery (market) samples in UK waters during 2004-05. Concentrations of Cd were generally higher in the ommastrephids, in all tissues except muscle. Hg concentrations were higher in $T$. sagittatus than in the loliginids. In L. forbesi, metal concentrations differed between tissues and also varied in relation to body size, geographic origin, and season. Cd levels decreased with increasing body size. This may be related to a shift in the diet with growth, since small $L$. forbesi feed on benthic invertebrates that have relatively high $\mathrm{Cd}$ concentrations, whereas larger individuals prey mainly on fish that have low $\mathrm{Cd}$ concentrations. $\mathrm{Hg}$ levels increased with body size, indicating its retention, and they were highest at the end of the spawning season and in squid from the English Channel and the Scottish West Coast. It is likely that the ambient concentration of $\mathrm{Hg}$ in seawater plays an important part in its accumulation in squid tissues. As it is a short-lived species, $L$. forbesi may therefore function as a bioindicator species for $\mathrm{Hg}$ contamination of the marine environment. Our results indicate that there is no significant danger to humans from consuming squid from UK waters.
\end{abstract}

Keywords: Cephalopods; Heavy metals; Trace elements; Bioaccumulation; Risk for human consumption 
Introduction

The commercial significance of cephalopods to world fisheries is of relatively recent, but growing importance (Boyle and Pierce, 1994; Boyle and Rodhouse, 2006). In the 1990s alone there was a $40 \%$ increase in squid catches worldwide (FAO data, 2003). In UK waters, the main commercial cephalopod species are the demersal long-fin squid Loligo forbesi and $L$. vulgaris, and the cuttlefish Sepia officinalis (Pierce et al., 1994a,b, 1998; Dunn, 1999; ICES, 2006). Annual landings of long-fin squid into the UK from adjacent waters varied from 1400 to 3000 tonnes during 1997-2004. These figures include landings of L. forbesi, L. vulgaris and the smaller Alloteuthis spp. Much of the squid landed in the UK is exported to southern Europe (Shaw, 1994). Landings of cuttlefish into the UK ranged from 1600 to 4900 tonnes during 1997-2004 (ICES, 2006). All these species occur in coastal, continental shelf waters. While S. officinalis and L. vulgaris are common only in the English Channel, the distribution of L. forbesi extends throughout UK waters (Roper et al., 1984). Three species of the mainly pelagic and oceanic short-fin squid family Ommastrephidae also occur in UK waters, namely Illex coindetii, Todarodes sagittatus and Todaropsis eblanae. All are of lesser commercial importance in UK waters, although some landings are reported from England and Wales (ICES, 2006). The lesser flying squid T. eblanae is most frequently recorded ommastrephid in coastal areas and occasionally occurs in very large numbers (Hastie et al., 1994). All squid are carnivorous, feeding mainly on crustaceans, small fish and other cephalopods, including conspecifics (Collins et al., 1994; Pierce et al., 1994c; Collins and Pierce, 1996; Lordan et al., 1998; Quetglas et al., 1999). Squid are themselves important prey items for large fish, seabirds and marine mammals (Croxall and Prince, 1996; Smale, 1996 ; Pierce and Santos, 1996; Santos et al., 2001).

The UK continental shelf is of high economic interest for present and future hydrocarbon exploration. Oil production activities could lead to increased releases of heavy metals resulting in increased bioaccumulation in marine biota, particularly in cephalopods, since they are very efficient accumulators of various trace elements (e.g. Martin and Flegal, 1975; Miramand and Bentley, 1992; Bustamante et al., 2002a). Toxic metals such as cadmium (Cd) and mercury $(\mathrm{Hg})$ are very efficiently bioaccumulated and retained in squid (Bustamante et al., 1998a, 2006a) and consequently passed on to predators, thus potentially increasing the contaminant load in higher trophic levels, including humans (Bustamante et al., 1998a; Lahaye et al., 2005; Storelli et al., 2005, 2006). 
Metals are also toxic for marine biota above a certain threshold. The early life stages (embryos and juveniles) of invertebrates are particularly sensitive to contaminants (Calabrese et al., 1973; Martin et al., 1981; Warnau et al., 1996). This is especially obvious when the spawning and the subsequent embryonic development occur directly in seawater, allowing direct contact of waterborne contaminants with the embryos and larvae, as in the case of squids (Villanueva and Bustamante, 2006). In addition to the potential direct effects of metals on squid embryos and juveniles, an increase of contamination levels in the environment is also likely to affect the reproductive tissues, potentially impacting on fertility and egg production (e.g. Gerpe et al., 2000; Craig and Overnell, 2003; Seixas et al., 2005; Miramand et al., 2006; Villanueva and Bustamante, 2006).

Overall, there is a lack of published data concerning the natural variations in metal concentrations in squids from UK waters. Such baseline information is needed to quantify the impact of anthropogenic contaminant sources (e.g. oil production activities) on these species. The main aim of this study was to provide baseline data on $\mathrm{Cd}$ and $\mathrm{Hg}$ concentrations in the tissues of different squid species from different seasons and regions around the UK and to identify and quantify sources of variation (e.g. seasonal, regional and ontogenetic). Biological data were also collected to provide a contemporaneous picture of the distribution of size, maturity and sex ratio. Although this investigation focused on L. forbesi, due to its wide distribution in coastal waters and high commercial importance, tissues from other common squid species in UK waters (Alloteuthis sp., T. eblanae and T. sagittatus) were also analysed for comparison.

Material and Methods

\section{Sampling and biological data collection}

A total of 3309 squid was collected and measured over 13 months (March 2004 to March 2005). The majority of data collected for L. forbesi $(n=1902)$ arose from five demersal trawling surveys carried out by the FRS Marine Laboratory between March 2004 and March 2005 in British waters (Table 1). During these surveys, samples of Alloteuthis sp. $(n=1216)$, T. eblanae $(n=86)$ and $T$. sagittatus $(n=17)$ were also collected. Additional samples of $L$. forbes $i$ were obtained from a research cruise in the Irish Sea in October $2004(n=50)$ and 
from a market sample of L. forbesi fished in the English Channel in July $2004(n=50)$. For all these squid, dorsal mantle length (DML), wet weight (g), sex, and maturity stage were recorded. DML was measured to the nearest $10 \mathrm{~mm}$. A standard 5-point scale of sexual maturity for L. forbesi was used (Pierce et al., 1994b, adapted from Lipinski, 1979), in which stage 1 is 'immature', stages 2-3 are 'maturing' and stages 4-5 are 'mature'. Specimens with no visible gonad development were classified as 'juveniles' and allocated to maturity stage 1.

Sub-samples of whole squid from each sample were stored frozen $\left(-20^{\circ} \mathrm{C}\right)$ for subsequent tissue sampling. A total of 282 squid from four species, i.e. 171 L. forbesi (mean DML: $129 \pm$ $78 \mathrm{~mm}$ ), 74 Alloteuthis sp. (mean DML: $67 \pm 15 \mathrm{~mm}$ ), 25 T. eblanae (mean DML: $100 \pm 41$ $\mathrm{mm}$ ) and 12 T. sagittatus (mean DML: $343 \pm 100 \mathrm{~mm}$ ) was analysed for concentrations of Cd and $\mathrm{Hg}$. The total number of squid analysed was limited by available funding. During each cruise, squid were selected by stratified random sampling, with the aim of obtaining a representative size range for both sexes from as many area/season combinations as possible.

\section{Metal analysis}

Metal concentrations were measured in weighed samples (around 5g) from digestive gland, mantle, gonads, gills and the homogenised combined remaining tissues, including head, arms and viscera. Normally, each tissue of each animal was processed separately but if the total weight of the tissue was very small (e.g. digestive glands of Alloteuthis sp.), samples were pooled for animals of the same sex and similar maturity stages or size for each haul. Gonads of juvenile and stage 1 squids were too small to sample, as were gonads, gills and combined remaining tissues of Alloteuthis spp.

Tissue samples were weighed, homogenised and freeze-dried. Dry weight of the samples was then recorded (and original moisture content estimated) prior to preparation for trace element analysis by atomic absorption spectrophotometry. For $\mathrm{Cd}$ analysis, the samples were digested with 4:1 v:v $65 \%$ ultrapure $\mathrm{HNO}_{3}$ and ultrapure $70 \% \mathrm{HClO}_{4}$ at $80^{\circ} \mathrm{C}$ for 2 days. The acids were then evaporated and the residues were dissolved in $0.3 \mathrm{~N}$ ultrapure nitric acid (Bustamante et al. 1998a). Cd analyses were carried out using an atomic absorption spectrophotometer Hitachi Z-5000 with Zeeman background correction. For Hg analysis, two aliquots ranging from 10-50 mg of dried material were directly analysed in an Advanced Mercury Analyser spectrophotometer (Altec AMA 254) as previously reported (Bustamante 
et al., 2006a). Reference tissues - dogfish liver (DOLT-3, NRCC) and lobster hepatopancreas (TORT-2, NRCC) - were treated and analysed in the same way as the samples. Results were in good agreement with the certified values and recoveries of the elements ranged from 97$103 \%(n=5)$. Detection limits were 0.004 and $0.005 \mu \mathrm{g} \cdot \mathrm{g}^{-1} \mathrm{dwt}$ for $\mathrm{Cd}$ and $\mathrm{Hg}$, respectively. Concentrations of both metals were expressed relative to both the dry weight of tissue $\left(\mu \mathrm{g} \cdot \mathrm{g}^{-1}\right.$ $\mathrm{dwt})$ and the wet weight of tissue $\left(\mu \mathrm{g} \cdot \mathrm{g}^{-1} \mathrm{wwt}\right)$. The former values are used for statistical analysis, to eliminate any effects of varying moisture content while the latter are used for calculating risks associated with consumption of squid tissue.

\section{Data analysis}

Differences in metal concentrations $\left(\mu \mathrm{g} \cdot \mathrm{g}^{-1} \mathrm{dwt}\right)$ between species were tested on logtransformed data using ANOVA with Tukey tests. For L. forbesi, Gaussian GAMs were fitted to the log-transformed data on metal concentrations, using BRODGAR 2.5.1 statistical software, to identify spatial, temporal, sex- and size-related trends. Season and location were treated as categorical explanatory variables. Haul locations were grouped into the following area codes: IS = Irish Sea $\left(52^{\circ} 35^{\prime} \mathrm{N}-54^{\circ} 19^{\prime} \mathrm{N}\right.$ and $\left.3^{\circ} 54^{\prime} \mathrm{W}-5^{\circ} 46^{\prime} \mathrm{W}\right)$, IW $=$ Irish West Coast $\left(52^{\circ} 42^{\prime} \mathrm{N}-55^{\circ} 57 \mathrm{~N}\right.$ and $\left.8^{\circ} 51 \mathrm{~W}-11^{\circ} 30 \mathrm{~W}\right), \mathrm{SWC}=$ Scottish West Coast $\left(56^{\circ} 09 \mathrm{~N}\right.$ $-59^{\circ} 20^{\prime} \mathrm{N}$ and $\left.5^{\circ} 09^{\prime} \mathrm{W}-9^{\circ} 30^{\prime} \mathrm{W}\right), \mathrm{MF}=$ Moray Firth $\left(57^{\circ} 40^{\prime} \mathrm{N}-58^{\circ} 13^{\prime} \mathrm{N}\right.$ and $2^{\circ} 34^{\prime} \mathrm{W}$ $\left.-3^{\circ} 25^{\prime} \mathrm{W}\right)$, NSUK $=$ North Sea Coast of the UK $\left(55^{\circ} 54^{\prime} \mathrm{N}-57^{\circ} 45^{\prime} \mathrm{N}\right.$ and $1^{\circ} 49^{\prime} \mathrm{W}-2^{\circ} 14^{\prime}$ $\mathrm{W}), \mathrm{EC}=$ English Channel (data not available) and NS = North Sea $\left(54^{\circ} 43^{\prime} \mathrm{N}-57^{\circ} 40^{\prime} \mathrm{N}\right.$ and $\left.2^{\circ} 37^{\prime} \mathrm{E}-0^{\circ} 59^{\prime} \mathrm{W}\right)$. Months were grouped into three "seasons", January to April, May to August and September to December (Table 1).

Since between-species differences in metal concentrations were not consistent across all organs, when possible, we also estimated average concentrations across all organs, as a weighted average of the individual organ concentrations. Complete data were available for 71 L. forbesi, 4 T. eblanae and 5 T. sagittatus. Although the sample sizes for the ommastrephids are very small we used ANOVA on log-transformed data to test whether differences between species were significant.

The health effects of $\mathrm{Cd}$ and $\mathrm{Hg}$ on humans from dietary sources have been repeatedly assessed by the Joint FAO/WHO Expert Committee on Food Additives (JECFA). The Committee allocated a Provisional Tolerable Weekly Intake for $\mathrm{Cd}$, total $\mathrm{Hg}$ and methyl $\mathrm{Hg}$ 
of 7, 5 and $1.6 \mu \mathrm{g} \cdot \mathrm{kg}^{-1} \cdot \mathrm{wk}^{-1}$ for humans, respectively (WHO 2003). The weight of cephalopod tissue that would need to be eaten to reach these limits for $\mathrm{Cd}$ and total $\mathrm{Hg}$ was calculated for each species (in $\mathrm{Kg}$ ) for an average person of $60 \mathrm{Kg}$ and is called "maximum safe weekly consumption" (MSWC). Estimations of the amount of squid flesh to reach the PTWI for methyl $\mathrm{Hg}$ were based on reported data concerning organic $\mathrm{Hg}$ proportion in cephalopods from the North East Atlantic waters (Bustamante et al. 2006).

Results

Biological data

Loligo forbesi of both sexes were smallest in spring 2004 and reached maximum average size in winter. The proportions of mature animals were highest in winter and spring and lowest from April to June (Table 1). Squid caught in spring 2005 were significantly larger and more mature than squid caught in spring 2004 (Table 1). Mature L. forbesi were recorded in the English Channel in July. Apart from the Scottish sample collected in July, the proportion of male squid amongst the mature squid caught was always higher than that of female squid. Small immature specimens were present in most months, although the proportion of these "recruits" increased during the summer.

\section{Between-species differences in Cd concentration}

Concentrations of $\mathrm{Cd}$ were highest in the digestive gland for all species (Table 2), ranging from 1.83 to $98.0 \mu \mathrm{g} . \mathrm{g}^{-1} \mathrm{dwt}$ for T. eblanae and from 9.61 to $215 \mu \mathrm{g} . \mathrm{g}^{-1} \mathrm{dwt}$ for T. sagittatus showing the highest concentrations. These concentrations were up to 30 times higher than

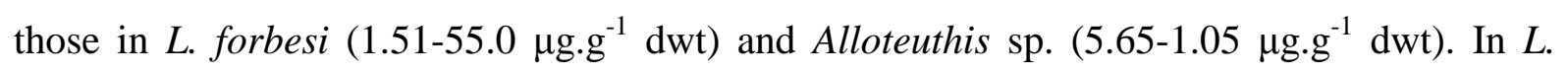
forbesi, the combined remaining tissues showed the second highest Cd concentration (after digestive gland), while both $T$. eblanae and T. sagittatus had higher metal concentrations in their gills (Table 2). The tissue with the lowest $\mathrm{Cd}$ concentrations was muscle for $L$. forbesi and $T$. sagittatus and gonadal tissue for T. eblanae. Cd concentrations in muscle tissue were highest for Alloteuthis sp. and T. eblanae.

ANOVA confirmed that Cd concentrations ( $\mu \mathrm{g} \cdot \mathrm{g}^{-1} \mathrm{dwt}$, log-transformed) in digestive gland varied significantly between species $\left(\mathrm{F}_{3,139}=10.35, \mathrm{P}<0.001\right)$, being significantly higher in $T$. 
sagittatus than in all the other species and significantly higher in T. eblanae than in L. forbesi (Tukey tests).

Although there was significant variation between species in muscle Cd concentrations $\left(\mu \mathrm{g} \cdot \mathrm{g}^{-1}\right.$ dwt, log-transformed $)\left(\mathrm{F}_{3,152}=14.08, \mathrm{P}<0.001\right)$, trends were different to those in digestive gland, with Cd concentrations being significantly higher in Alloteuthis sp. and T. eblanae than in T. sagittatus and L. forbesi, and significantly higher in T. sagittatus than in L. forbesi.

For Cd concentrations in gills, gonads, combined other tissues, and the overall average for the body, statistical comparisons were possible only for the three larger species. There was significant between species variation in Cd concentration ( $\mu \mathrm{g} \cdot \mathrm{g}^{-1} \mathrm{dwt}, \log$-transformed) in gills $\left(\mathrm{F}_{2,88}=44.37, \mathrm{P}<0.001\right)$. Concentrations were significantly higher in both ommastrephids than in L. forbesi. There was also significant between species variation in Cd concentration in gonads $\left(\mathrm{F}_{2,54}=6.19, \mathrm{P}=0.004\right)$, with significantly higher values in $T$. sagittatus than in $L$. forbesi. Between-species variation in $\mathrm{Cd}$ concentration of combined other tissues was marginally significant $\left(\mathrm{F}_{2,87}=3.23, \mathrm{P}=0.044\right)$. Although the lowest values were seen in $L$. forbesi none of the paired comparisons indicated a significant difference. Overall average $\mathrm{Cd}$ concentration in the body varied significantly between species $\left(\mathrm{F}_{2,77}=29.32, \mathrm{P}<0.001\right)$, with significantly higher concentrations in both ommastrephids than in L. forbesi.

\section{Between-species differences in Hg concentration}

$\mathrm{Hg}$ concentrations tended to be slightly higher in the digestive gland than in other tissues of all species except for Alloteuthis sp., in which Hg levels were similar to those found in the muscle tissue (Table 2).

There was significant between-species variation in $\mathrm{Hg}$ concentrations $\left(\mu \mathrm{g} \cdot \mathrm{g}^{-1} \mathrm{dwt}, \mathrm{log}-\right.$ transformed $)$ in digestive gland $\left(\mathrm{F}_{2,139}=7.80, \mathrm{P}<0.001\right)$. Concentrations were significantly higher in T. sagittatus than in T. eblanae and A. subulata, while L. forbesi also had higher concentrations than A. subulata. For muscle tissue, again overall variation was significant $\left(\mathrm{F}_{2,149}=12.08, \mathrm{P}<0.001\right)$; concentrations were higher in $T$. sagittatus than the other three species and higher in L. forbesi than in A. subulata. 
Analysis for other tissues was restricted to the three larger species. Although T. sagittatus tended to have the highest concentrations, between species variation in $\mathrm{Hg}$ concentration in gills was not significant $\left(\mathrm{F}_{2,87}=2.73, \mathrm{P}=0.071\right)$. There was significant variation for gonad $\left(\mathrm{F}_{2,54}=4.49, \mathrm{P}=0.016\right)$, other tissues $\left(\mathrm{F}_{2,87}=4.64, \mathrm{P}=0.012\right)$ and the all tissues average $\left(\mathrm{F}_{2,77}=\right.$ 4.52, $\mathrm{P}=0.014$ ), with higher concentrations in $T$. sagittatus than in $L$. forbesi in all cases.

\section{Trends in Cd concentrations in Loligo forbesi}

A summary of $\mathrm{Cd}$ concentrations in the different tissues of $L$. forbesi from the different sampling areas and at different seasons is presented in Table 3. The final GAM for Cd concentrations ( $\mu \mathrm{g} \cdot \mathrm{g}^{-1} \mathrm{dwt}$, log-transformed) in the digestive gland tissue of $L$. forbesi explained $80 \%$ of deviance $(\mathrm{N}=105$, AIC $=-62.4)$. There was no difference between the sexes but the effect of body size (DML) was highly significant $(\mathrm{P}<0.0001)$. Cd concentration decreased ( $\mathrm{df}=2.73$ ) with DML, although with a steeper decline in small animals (Fig 1a). There were also significant effects of the season, with values in March being higher than in January and values in the last four months of the years being lower than those in the first four months $(\mathrm{P}<0.0001)$. There was also significant geographic variation with concentrations in squid from the English Channel (selected as the reference area) being lower than those from other areas $(\mathrm{P}<0.0001)($ Fig 2$)$.

The final model for $\mathrm{Cd}$ in muscle explained $54 \%$ of deviance $(\mathrm{N}=101)$ and was similar in that Cd concentration decreased with DML $(\mathrm{df}=2.58, \mathrm{P}<0.001)$. However, seasonal differences were non-significant and the only area effect was for higher concentrations to be seen in the English Channel than in the Irish Sea $(\mathrm{P}=0.002)$.

The final model for $\mathrm{Cd}$ in gills explained $58 \%$ of deviance $(\mathrm{N}=78)$ and included effects of DML (d.f. $=3.73, \mathrm{P}<0.001$; a negative trend up to around $200 \mathrm{~mm}$ DML after which no further crease is seen) and area: all areas except the west coasts of Ireland and Scotland showed lower Cd concentrations than in the English Channel.

In the case of gonad tissue, the final model included DML ( $\mathrm{df}=1, \mathrm{P}=0.008)$, in this case a positive linear effect, season (lower values in the last four months of the year than in the first four months, $\mathrm{P}=0.005$ ) and area (lower concentrations in the North Sea and Moray Firth than 
in the English Channel, $\mathrm{P}=0.023$ and $\mathrm{P}=0.037$ respectively). This model explained $42 \%$ of deviance $(\mathrm{N}=47)$.

The final model for $\mathrm{Cd}$ concentrations in other tissues included DML $(\mathrm{df}=2.61, \mathrm{P}<0.001)-$ an initially negative relationship reaching an asymptote around $250 \mathrm{~mm}$ - and season, with higher values in the first four months of the year than in the second and third periods $(\mathrm{P}<0.001)$.

\section{Trends in Hg concentrations in L. forbesi}

A summary of $\mathrm{Hg}$ concentrations in the different tissues of L. forbesi from the different sampling areas and at different seasons is presented in Table 3. The final GAM for $\mathrm{Hg}$ concentrations ( $\mu \mathrm{g} \cdot \mathrm{g}^{-1} \mathrm{dwt}$, log-transformed) in the digestive gland tissue of $L$. forbesi explained $84 \%$ of deviance $(\mathrm{N}=105$, AIC $=-126.6)$. There was marginally significant trend for higher values in males $(\mathrm{P}=0.038)$ but this was dropped from the final model to increase sample sizes (around 20 animals could not be sexed). No difference between the sexes but the effect of body size (DML) was also highly significant $(\mathrm{P}<0.0001)$. Hg concentration increased linearly with increasing DML (Fig 1b). There were also significant effects of season, with values in January to April being higher than in the rest of the year $(\mathrm{P}<0.001) . \mathrm{Hg}$ concentrations in the English Channel were higher than in all other areas except the North Sea $(\mathrm{P}<0.001)$.

In the case of muscle, the best model of $\mathrm{Hg}$ concentration explained $85 \%$ of deviance $(\mathrm{N}=101)$, including a positive linear effect of DML $(\mathrm{P}<0.001)$, higher concentrations in the English Channel than in the North Sea $(\mathrm{P}=0.011)$, Moray Firth $(\mathrm{P}<0.001)$ and North Sea coastal waters $(\mathrm{P}<0.001)$, and higher concentration in the first four months of the year than in thre last 4 months $(\mathrm{P}<0.001)$.

For gills, the best model explained $90 \%$ of deviance $(\mathrm{N}=78)$, including a positive effect of DML $(\mathrm{df}=2.05, \mathrm{P}<0.001)$, higher concentrations in the first four months of the year than in the second and third periods $(\mathrm{P}<0.001)$ and higher concentrations in the English Channel than in the North Sea, Moray Firth and North Sea coasts ( $\mathrm{P}<0.001$ in all cases). 
The best model for $\mathrm{Hg}$ in gonads explained $83 \%$ of deviance $(\mathrm{N}=47)$ and included a weak positive effect of DML ( $\mathrm{df}=1.71, \mathrm{P}=0.031)$, higher values in the first four months of the year than the last four $(\mathrm{P}<0.001)$ and higher values in the English Channel than in the North Sea $(\mathrm{P}=0.014)$ and Moray Firth $(\mathrm{P}<0.001)$.

Finally, the best model for $\mathrm{Hg}$ in other tissues explained $86 \%$ of deviance $(\mathrm{N}=77)$ and included a positive linear effect of DML $(\mathrm{P}<0.001)$, higher values in the first four months of the year than the last four $(\mathrm{P}<0.001)$ and higher values in the English Channel than in the North Sea $(\mathrm{P}=0.026)$, Moray Firth $(\mathrm{P}<0.001)$ and North Sea coasts $(\mathrm{P}<0.001)$ and higher values in the Irish Sea than in the English Channel $(\mathrm{P}=0.034)$.

As was apparent from the modelling results, data from different tissues of $L$. forbesi give somewhat different pictures of the geographical distribution of metal concentrations (Fig 2). These plots do however show that $\mathrm{Hg}$ levels were consistently highest in all tissues of squid from the English Channel. Interestingly, these squids also displayed the lowest $\mathrm{Cd}$ concentrations in their tissues, with the exception of the gonads.

\section{Implications for public health}

To exceed the PWTI for Cd (i.e. $7 \mu \mathrm{g} \cdot \mathrm{kg}^{-1} \cdot \mathrm{wk}^{-1}$ ), it would be necessary to ingest from 27 to $333 \mathrm{~g}$ of squid muscle per $\mathrm{kg}$ of body weight for an average human body weight of $60 \mathrm{~kg}$. This represents consumption of 1.6 to $20 \mathrm{~kg}$ of squid muscle in a week (Table 2). However, the PTWI would be reached with only 15 g. $\mathrm{wk}^{-1}$ for the digestive gland of the four squid species and for the gills of T. sagittatus (Table 2). This may be an issue in countries (e.g. Japan), where squid digestive glands are consumed. In southern Europe, small squids are often eaten whole but the viscera of larger squid would not normally be eaten.

In relation to $\mathrm{Hg}$ intake, the amount of squid tissue to reach the PTWI for total $\mathrm{Hg}\left(5 \mu \mathrm{g} \cdot \mathrm{kg}^{-}\right.$ ${ }^{1} \cdot \mathrm{wk}^{-1}$ ) would be around $9 \mathrm{~kg}$ of Loligo or Todaropsis flesh per week or around $4 \mathrm{~kg}$ of Todarodes flesh. Even for the tissue with the highest $\mathrm{Hg}$ concentration, i.e. the digestive gland of Todarodes, it would be necessary to eat more than $2.7 \mathrm{~kg} \cdot \mathrm{wk}^{-1}$ to exceed safe limits (Table 2). Knowing that from 70 to $90 \%$ of $\mathrm{Hg}$ in squid tissues would be under organic form (Bustamante et al. 2006), the amount of squid flesh to reach the methyl Hg PTWI would be 
3.5 to 4.5 times lower compare to the values for total $\mathrm{Hg}$, i.e. between 2 to $2.6 \mathrm{~kg}$ of Loligo or Todaropsis flesh per week and between 0.9 to $1.1 \mathrm{~kg}$ of Todarodes flesh.

\section{Discussion}

The biological data collected are largely consistent with previous findings for L. forbesi in Scottish waters (e.g. Boyle and Pierce, 1994; Collins et al., 1997). The L. forbesi population sampled in spring 2004 was already past the peak of its spawning season. Mature and large squid were absent in August in the Northern part of the North Sea, suggesting that they had either died or emigrated from fished areas. Following recruitment of the next generation, maturity subsequently increased in autumn and winter. However, mature squid were recorded from the English Channel in July 2004, which could represent the summer spawning group that has previously been identified in the English Channel (Holme, 1974). The presence of small immature specimens in most months suggests that some recruitment occurs throughout the year, as previously recorded by Lum-Kong et al. (1992). A higher proportion of mature animals was found in March 2005 than March 2004. Since both surveys covered the same areas, this suggests that the spawning season started earlier in 2005. Interannual variation in the timing of life-cycle events (e.g. migrations, maturation) has been previously documented in this species and is likely to be linked to environmental variation (Sims et al., 2001; Pierce et al., 2005).

Higher $\mathrm{Cd}$ concentrations were found in the digestive gland of all species compared to the other tissues, reflecting the digestive gland's role in the storage and detoxification of this metal (e.g. Miramand and Guary, 1980; Tanaka et al., 1983; Finger and Smith, 1987; Miramand and Bentley, 1992; Bustamante et al., 2002a,b). For Hg, the concentrations recorded in all tissues were generally in the same order of magnitude compared to the digestive gland. Such different patterns of accumulation for $\mathrm{Cd}$ and $\mathrm{Hg}$ suggest that cephalopods have different mechanisms/rates of uptake and/or sequestration of these two metals. Sources of metals to cephalopods are 1) seawater, as it passes through the skin and through the gills and 2) diet, which probably represents the main pathway for many elements - as previously shown for Am, Cd, Co or Zn (Koyama et al., 2000; Bustamante et al., 2002a, 2004, 2006b; Miramand et al., 2006). To the best of our knowledge, Hg uptake and retention has not been fully investigated in cephalopods. Mechanisms of uptake and depuration of $\mathrm{Hg}$ can be influenced by the speciation of the metal in both seawater and prey. However, 
compared to $\mathrm{Cd}$, the role of the digestive gland in the storage of $\mathrm{Hg}$ appears to be relatively limited in loliginid and ommastrephid species in UK waters (see Table 3). This may be due to: 1) an excretion function of $\mathrm{Hg}$ by the digestive gland, and 2) a preferential redistribution of $\mathrm{Hg}$ to muscular tissues where it bound to the sulphydryl groups of proteins (Bloom, 1992; Bustamante et al., 2006a). Further research focusing on $\mathrm{Hg}$ detoxification, storage and excretion in cephalopods would be worthwhile.

In contrast to $\mathrm{Hg}, \mathrm{Cd}$ concentrations in the digestive gland exhibit high variability in the four species tested, i.e. from 9.48 to $65.3 \mu \mathrm{g} . \mathrm{g}^{-1} \mathrm{dwt}$, with the lowest concentrations found in loliginids and the highest in ommastrephids (Table 2). This result is in accordance with previous observations in the north east Atlantic waters (e.g. Bustamante et al., 1998a) and from the Mediterranean Sea (e.g. Bernardi et al., 2004). Since dissolved Cd concentrations are higher in coastal waters than the open ocean, loliginids might be expected to have higher Cd concentrations in their tissues than ommastrephids, which tend to have a less coastal distribution. Since the majority of the $\mathrm{Cd}$ in cephalopod tissues is probably derived from the diet (Koyama et al., 2000; Bustamante et al., 2002a), differences in feeding could contribute to differences in Cd contamination. Both $L$. forbesi and T. sagittatus are largely piscivorous but the latter may take more pelagic and fewer demersal and benthic prey (Collins et al., 1994; Pierce et al., 1994c; Quetglass et al., 1999). Differences in physiological characteristics of loliginids and ommastrephids may also explain the differences observed. With regard to tissue ultrastructure, the digestive gland cells of loliginids do not contain the "boule" structures characteristic of most cephalopod species (Boucher-Rodoni and Boucaud-Camou, 1987). These are generally considered to be heterolysosomes and heterophagosomes involved in intracellular digestion (Boucaud-Camou, 1976; Boucaud-Camou and Yim, 1980). A lack of "boules", therefore could result in a reduction of particle capture, limiting intracellular digestion (Boucher-Rodoni and Boucaud-Camou, 1987). Overall, the lysosomal system of loliginids is less developed than in other cephalopod species and these squids could be physiologically limited to storing and detoxifying $\mathrm{Cd}$ via binding to insoluble compounds. Alternatively, these squids may also have developed mechanisms favouring the excretion of Cd (Bustamante et al., 2002b).

The more extensive sampling of L. forbesi allowed investigation of the variation of Cd and $\mathrm{Hg}$ concentrations with biological and environmental factors, such as age (size), sex, lifestyle and geographic origin. In this species, Cd concentrations decreased with increasing body size 
and tissues showed significantly different Cd loads according to the geographic origin of the animals sampled. The decrease of $\mathrm{Cd}$ concentrations could reflect a shift in their diet with increasing body size. Juvenile $L$. forbesi have a crustacean-dominated diet whereas the adults consume more fish (Collins and Pierce, 1996). Fish generally exhibit lower Cd concentrations than invertebrates (Cossa and Lassus, 1988). Therefore the diet of smaller squid feeding on invertebrates would be richer in $\mathrm{Cd}$ than the diet of bigger squid feeding predominantly on fish. Furthermore, the decrease of Cd concentrations may be strengthened by the dilution of the metal in the tissues due to the very fast growth of this squid. A similar ontogenetic decrease of $\mathrm{Cd}$ concentrations has been reported for the mantle muscle of other cephalopod species, e.g. Octopus salutii and Eledone cirrhosa from the Mediterranean Sea (Barghigiani et al., 1993, Storelli and Marcotrigiano, 1999). For O. salutii, this trend was related to its reproductive cycle, since adult females approach the coast to lay their eggs. Therefore, young octopods, having very high trophic activity, are proportionally more exposed to pollution in coastal sites (Storelli and Marcotrigiano, 1999). However, an opposite trend was found for the cuttlefish S. officinalis from the English Channel, especially when considering $\mathrm{Cd}$ concentration in the digestive gland (Miramand et al., 2006). In cuttlefish, Cd appears to be strongly retained in this tissue, with a biological half-life exceeding eight months (Bustamante et al., 2002b). These contradictory results among cephalopod orders show that investigations on $\mathrm{Cd}$ metabolism should be carried on a wider range of cephalopod species, including octopus and squid species.

Unlike the other tissues, the Cd concentrations in gonads increased with size, the highest values being found in winter when squids reach sexual maturity. Higher Cd levels were also reported in the gonads of mature squid Illex argentinus from the South Atlantic Ocean compare to immature ones (Gerpe et al., 2000). Interestingly, $\mathrm{Cd}$ and $\mathrm{Hg}$ varied positively, suggesting a common elimination through the gonads. Although difficult to assess, Cd and $\mathrm{Hg}$ accumulation in gonadal tissues may occur as a result of the accumulation of essential elements to supply the embryo's needs (Villanueva and Bustamante, 2006). Essential elements such as $\mathrm{Zn}$ are stored in metal-containing enzymes and metalloproteins within the ovary. $\mathrm{Cd}$ and $\mathrm{Hg}$ are well-known for its affinity to $\mathrm{Zn}$ binding sites, particularly in $\mathrm{SH}-$ containing proteins such as metallothioneins (Niboer and Richardson, 1980, Cosson et al., 1991, George and Olsson, 1994) and could therefore accumulate bound to such proteins. To the best of our knowledge, there are no studies reporting the occurrence of metallothionein in the gonads of cephalopods. As there were significant differences of $\mathrm{Cd}$ and $\mathrm{Hg}$ levels between 
areas, the effect of this metal accumulation on the squid fertility and the egg production should be evaluated in the future.

Environmental factors, i.e. geographic origin and season also influenced $\mathrm{Cd}$ concentrations in L. forbesi tissues (Table 3, Fig 2). However, the pattern of variation was different according to the tissue considered and to the season. With the exception of the gonads and gills, $\mathrm{Cd}$ concentrations were generally lower in squids from the English Channel, suggesting that they were less exposed to the metal from the dietary pathway. This is, at first sight, surprising, in that anthropogenic activities would be expected to increase the Cd contamination in the food webs from this area. However, $\mathrm{Cd}$ occurs naturally at very high concentrations in cephalopods from remote and pristine areas such as the Austral Ocean and Northern Atlantic waters (Bustamante et al. 1998ab). As a general rule, Cd concentrations in various phyla increased "naturally" from the temperate zone to sub-polar and polar waters (e.g. Rainbow 1989, Zauke \& Petri 1993, Bustamante et al. 1998a, 2003). Even though our sampling represents a restricted latitudinal range, it is possible that the low $\mathrm{Cd}$ concentrations in squids from the English Channel result from a natural latitudinal trend.

In contrast to $\mathrm{Cd}, \mathrm{Hg}$ levels increased with size of $L$. forbesi and were highest at the end of the spawning season. In aquatic animals, $\mathrm{Hg}$ concentrations may vary according to their trophic level and age. As it is mainly stored in the methylated form in biota, $\mathrm{Hg}$ consistently biomagnifies through the food chain, with predators showing higher tissue concentrations than are found in their prey. In cephalopods, it is generally agreed that $\mathrm{Hg}$ tissue concentrations are positively correlated with body size (e.g. Rossi et al., 1993; Storelli and Marcotrigiano, 1999) and a similar relationship has also been reported for loliginid squid from the Azores, the Bay of Biscay, the Celtic Sea and the Faroe Bank (Monteiro et al., 1992; Bustamante et al., 2006a). Monteiro et al. (1992) reported a higher accumulation rate of $\mathrm{Hg}$ in L. forbesi females, suggesting physiological and/or ecological differences between the sexes. However, no sex-related differences were evident in the present study.

In addition, $\mathrm{Hg}$ levels were highest in squid from the English Channel and the Scottish West Coast and there was also seasonal variation. Higher $\mathrm{Hg}$ concentrations found in the tissues of L. forbesi from the English Channel (Fig. 2) could be related to human activities in the area. However, considering data for all species, no clear habitat (open water vs coastal) or latitude (north $v s$ south) differences could be found in $\mathrm{Hg}$ loads. Since squid have annual life-cycles 
and undertake regular seasonal migrations, it is difficult to differentiate ontogenetic, seasonal, and regional variation in metal concentrations. Although the relative contributions of dietary and waterborne pathways have not been assessed in cephalopods, it is expected that food would be the main source for $\mathrm{Hg}$ accumulation in squid tissues (Bustamante et al., 2006a). As cephalopods are short-lived species, they might therefore function as good indicator species of the variation of $\mathrm{Hg}$ concentrations in seawater and for marine pollution (Seixas et al. 2005).

Cephalopods may constitute a significant seafood source of human tissue burdens of Cd and Hg (Storelli and Marcotrigiano, 1999; Storelli et al., 2005). In most European countries, viscera are removed before consumption. In Italy and Spain, however, small Loligo spp. and Alloteuthis spp. are eaten whole, and people from these countries consume much of the $L$. forbesi landed in the UK and Northern France (Shaw, 1994). Moreover, in Japan, the digestive gland is consumed and is considered to be a delicacy. It was therefore important to evaluate the implication of metal levels in squid tissue for public health.

The maximum permitted levels of $\mathrm{Cd}$ and $\mathrm{Hg}$ for human consumption are 1.0 and $0.5 \mathrm{mg} \cdot \mathrm{kg}^{-1}$ fresh weight respectively (based on the consumption of seafood). The Joint FAO/WHO Expert Committee on Food Additives (JECFA) has established a Provisional Tolerable Weekly Intake (PTWI) of 7 and $5 \mu \mathrm{g} \cdot \mathrm{kg}^{-1} \cdot \mathrm{wk}^{-1}$ for Cd and $\mathrm{Hg}$, respectively (WHO, 1989, 1992, 2003). The quantities of $\mathrm{Cd}$ and $\mathrm{Hg}$ in the muscle of $L$. forbesi, (i.e. the tissue predominantly used for human consumption) were such that thresholds are very unlikely to be exceeded, with average levels of $\mathrm{Cd}$ measured at $0.02 \mu \mathrm{g} \cdot \mathrm{g}^{-1}$ and average levels of $\mathrm{Hg}$ measured at $0.04 \mu \mathrm{g} \cdot \mathrm{g}^{-1}$. For an adult human of $60 \mathrm{~kg}$ body weight, it would be necessary to eat at least $1.6 \mathrm{~kg} \mathrm{wk}^{-1}$ of $T$. eblanae muscle to reach the PTWI. For the other squid species studied, larger amounts would have to consumed, up to $20 \mathrm{~kg} \cdot \mathrm{wk}^{-1}$ in the case of L. forbesi. In southern Europe, the complete consumption of bodies of small squid (loliginids) may also contribute significantly to $\mathrm{Cd}$ intake, since their digestive glands account for $\sim 5 \%$ of total body mass. Based on a weighted average of Cd concentrations in muscle and digestive gland, the critical amounts of whole squid consumed to reach PTWI would be around $1.6 \mathrm{~kg}$. $\mathrm{wk}^{-1}$ for Alloteuthis spp. and around $2.3 \mathrm{~kg}$. $\mathrm{wk}^{-1}$ for L. forbesi. For total $\mathrm{Hg}$, the critical amounts of squid flesh ingested to reach the PTWI were always $>3.8 \mathrm{~kg} \cdot \mathrm{wk}^{-1}$ and even for digestive gland was consistently $>2.7 \mathrm{~kg} \cdot \mathrm{wk}^{-1}$ (Table 2). For methyl $\mathrm{Hg}$, the PTWI is only $1.6 \mu \mathrm{g} . \mathrm{kg}^{-}$ ${ }^{1}$. $\mathrm{wk}^{-1}$ (WHO 2003), and assuming that from 70 to $90 \%$ of the total $\mathrm{Hg}$ is under organic form 
in squid tissues (Bustamante et al. 2006), the critical amounts of squid muscle and digestive gland ingested were always $>$ to 1.1 and $>0.6 \mathrm{~kg} \cdot \mathrm{wk}^{-1}$, respectively. The results of this study indicate that squid fished in the areas investigated were, in terms of $\mathrm{Cd}$ and $\mathrm{Hg}$ concentration in selected tissues, safe for human consumption.

\section{Conclusions}

As heavy metal contamination of squid has potential implications for human health and conservation of marine mammals, it should be monitored on a regular basis. The observed differences between $\mathrm{Cd}$ levels in loliginids and ommastrephids need to be investigated further, in order to determine the possible influence of physiological differences and/or dietary changes during development. The digestive gland plays a major role in $\mathrm{Cd}$ bioaccumulation and detoxification in squid, but it seems to have a limited role in storage of $\mathrm{Hg}$. Observed seasonal variations indicate that squid can be used to monitor ambient $\mathrm{Hg}$ levels in the environment.

\section{Acknowledgements}

This study was commissioned and funded by Geotek Ltd and Hartley-Anderson Ltd in association with the UK Government Department of Trade and Industry's Strategic Environmental Assessment programme. We thank John Hartley for his support and advice throughout the period of the study. We thank Ian Tuck and Kevin Peach (Fisheries Research Services Marine Laboratory, Aberdeen), Jean-Paul Robin (Université de Caen) and Pieter-Jan Schön (Department of Agriculture and Rural Development, Northern Ireland) for provision of fishery data and samples. We also thank the FRS Marine Laboratory for the giving us the opportunity to participate in research cruise surveys, and Paulo Freitas and Paula Serafino for assistance with sampling. We also thank two referees for their useful comments.

\section{References}

Barghigiani, C., D'Ulivo, A., Zamboni, R., Lampugnani, L., 1993. Interaction between selenium and cadmium in Eledone cirrhosa of the Northern Tyrrhenian Sea. Mar. Pollut. Bull. 26, 212-216. 
Bernardi, C., Trezzi, I., Renon, P., Cattaneo, P., Malandra, R., 2004. Determinazione di piombo e cadmio in molluschi cefalopodi del Mediterraneo. Ind. Aliment. Italy 43, 1006-1008.

Bloom, N.S., 1992. On the chemical form of mercury in edible fish and marine invertebrate tissue. Can. J. Fish. Aquat. Sci. 49, 1010-1017

Boucaud-Camou, E., 1976. Structure et fonction de la glande digestive ("foie") de la Seiche, Sepia officinalis L. (Mollusque, Céphalopode). B. Soc. Zool. Fr. 101, 887.

Boucaud-Camou, E., Yim, M., 1980. Fine structure and function of the digestive cell of Sepia officinalis (Mollusca: Cephalopoda). J. Zool. 191, 89-105.

Boucher-Rodoni, R., Boucaud-Camou, E., 1987. Fine structure and absorption of ferritin in the digestive organs of Loligo vulgaris and L. forbesi (Cephalopoda, Teuthoidea). J. Morphol. 193, 173-184.

Boyle, P.R., Boletzky, S.v., 1996. Cephalopod populations: definitions and dynamics. Philos. T. Roy. Soc. B 351, 985-1002.

Boyle, P.R., Pierce, G.J., 1994. Fishery biology of northeast Atlantic squid: an overview. Fish. Res., 21, 1-16.

Bustamante, P., Caurant, F., Fowler, S.W., Miramand, P., 1998a. Cephalopods as a vector for the transfer of cadmium to top marine predators in the north-east Atlantic Ocean. Sci. Total Environ. 220, 71-80.

Bustamante, P., Cherel, Y., Caurant, F., Miramand, P., 1998b. Cadmium, copper and zinc in octopuses from Kerguelen Islands, Southern Indian Ocean. Polar Biol. 19, 264-271.

Bustamante, P., Teyssié, J.-L., Fowler, S.W., Cotret, O., Danis, B., Miramand, P., Warnau, M. 2002a. Biokinetics of zinc and cadmium accumulation and depuration at different stages in the life cycle of the cuttlefish Sepia officinalis. Mar. Ecol. Prog. Ser. 231, 167-177.

Bustamante, P., Cosson, R.P., Gallien, I., Caurant, F., Miramand, P., 2002b. Cadmium detoxification processes in the digestive gland of cephalopods in relation to accumulated cadmium concentrations. Mar. Environ. Res. 53, 227-241.

Bustamante, P., Bocher, P., Cherel, Y., Miramand, P., Caurant, F. 2003. Distribution of trace elements in the tissues of benthic and pelagic fish from the Kerguelen Islands. Sci. Tot. Environ. 313, 25-39.

Bustamante, P., Teyssié, J.-L., Danis, B., Fowler, S.W., Miramand, P., Cotret, O., Warnau, M., 2004. Uptake, transfer and distribution of silver and cobalt in tissues of the 
common cuttlefish Sepia officinalis at different stages of its life cycle. Mar. Ecol. Prog. Ser. 269, 185-195.

Bustamante, P., Lahaye, V., Durnez, C., Churlaud, C., Caurant, F., 2006a. Total and organic $\mathrm{Hg}$ concentrations in cephalopods from the North East Atlantic waters: influence of geographical origin and feeding ecology. Sci. Tot. Environ. 368, 585-596.

Bustamante, P., Teyssié, J.-L., Fowler, S.W., Warnau, M., 2006b. Assessment of the exposure pathway in the uptake and distribution of americium and cesium in cuttlefish (Sepia officinalis) at different stages of its life cycle. J. Exp. Mar. Biol. Ecol. 331, 198-207.

Caddy, J.F., Rodhouse, P.G., 1998. Do recent trends in cephalopod and groundfish landings indicate widespread ecological change in global fisheries. Rev. Fish Biol. Fisher. 8, 431-444.

Calabrese, A., Collier, R.S., Nelson, D.A., MacInnes, J.R., 1973. The toxicity of heavy metals to embryos of the American oyster Crassostrea virginica. Mar. Biol. 18, 162-166.

Caurant, F., Amiard-Triquet, C., 1995. Cadmium contamination in pilot whales Globicephala melas: source and potential hazard to the species. Mar. Pollut. Bull. 30, 207-210.

Collins, M.A., Burnell, G.M., Rodhouse, P.G., 1995. Recruitment, maturation, and spawning of Loligo forbesi (Cephalopoda: Loliginidae) in Irish waters. ICES J. Mar. Sci. 52, 127-137.

Collins, M.A., De Grave, S., Lordan, C., Burnell, G.M., Rodhouse, P.G., 1994. Diet of the squid Loligo forbesi Steenstrup (Cephalopoda: Loliginidae) in Irish waters. ICES J. Mar. Sci. 51, 337-344.

Collins, M.A., Pierce, G.J., 1996. Size selectivity in the diet of Loligo forbesi (Cephalopoda: Loliginidae). J. Mar. Biol. Assoc. U.K.. 76, 1081-1090.

Collins, M.A., Pierce, G.J., Boyle, P.R., 1997. Population indices of reproduction and recruitment in Loligo forbesi (Cephalopoda: Loliginidae) in Scottish and Irish waters. J. Appl. Ecol. 34, 778-786.

Cossa, D., Lassus, P., 1988. Le cadmium en milieu marin. Biogéochimie et écotoxicologie. Rapports Scientifiques et Techniques no. 16. IFREMER, Issy-les-Moulineaux, France.

Cosson, R.P., Amiard-Triquet, C., Amiard, J.C., 1991. Metallothioneins and detoxification. Is the use of detoxification proteins for MTs a language abuse? Water Air Soil Poll. 57/58, 555-567.

Craig, S., Overnell, J., 2003. Metals in squid, Loligo forbesi, adults, eggs and hatchlings. No evidence for a role for $\mathrm{Cu}$ - or Zn-metallothionein. Comp. Biochem. Phys. C. 134 , 311-317. 
Croxall, J.P., Prince, P.A., 1996. Cephalopods as prey. 1. Seabirds. Philos. T. Roy. Soc. B $351,1023-1043$.

Das, K., Debacker, V., Bouquegneau, J.M., 2000. Metallothioneins in marine mammals. Cell. Mol. Biol. 46, 283-294

Dunn, M.R., 1999. Aspects of the stock dynamics and exploitation of cuttlefish, Sepia officinalis (Linnaeus, 1758), in the English Channel. Fish. Res. 40, 277-293.

Elinder, C.G., Järup, L., 1996. Cd exposure and health risks: recent findings. Ambio 25, 370373

Finger, J.M., Smith, J.D., 1987. Molecular association of $\mathrm{Cu}, \mathrm{Zn}, \mathrm{Cd}$ and ${ }^{210} \mathrm{Po}$ in the digestive gland of the squid Nototodarus gouldi. Mar. Biol. 95, 87-91.

Gallien, I., Caurant, F., Bordes, M., Bustamante, P., Miramand, P., Fernandez, B., Quellard, N., Babin, P., 2001. Cadmium-containing granules in kidney tissue of the Atlantic white-sided dolphin (Lagenorhyncus acutus) off the Faroe Islands. Comp. Biochem. Phys. C 130, 389-395

George, S.G., Olsson, P.E., 1994. Metallothioneins as indicators of trace metal pollution. In: Kramer, K.J.M. (Ed.), Biomonitoring of coastal waters and estuaries. RC Press Inc., Boca Raton, pp. 151-171.

Gerpe, M.S., de Moreno, J.E.A., Moreno, V.J., Patat, M.L., 2000. Cadmium, zinc and copper accumulation in the squid Illex argentinus from the Southwest Atlantic Ocean. Mar. Biol. 136, 1039-1044.

Han, S.J., Park, J.S., Lee, I.S., 2003. Accumulation and elimination of cadmium and zinc in the Asian periwinkle Littorina brevicula. J. Environ. Sci. Heal. A 38, 965-974.

Hastie, L.C., Joy, J.B., Pierce, G.J., Yau, C., 1994. Reproductive biology of Todaropsis eblanae (Cephalopoda: Ommastrephidae) in Scottish waters. J. Mar. Biol. Assoc. U.K. 74, 367-382.

Holme, N.A., 1974. The biology of Loligo forbesi Steenstrup (Mollusca: Cephalopoda) in the Plymouth area. J. Mar. Biol. Assoc. U.K. 54, 481-503.

ICES, 2006. Report of the Working Group on Cephalopod Fisheries and Life History (WGCEPH), International Council for the Exploration of the Sea CM 2006/LRC:14.

Koyama, J., Nanamori, N., Segawa, S., 2000. Bioaccumulation of waterborne and dietary cadmium by oval squid Sepioteuthis lessoniana, and its distribution among organs. Mar. Pollut. Bull. 40, 961-967.

Lipinski, M., 1979. Universal maturity scale for the commercially important squids (Cephalopoda: Teuthoidea). The results of maturity classification of Illex illecebrosus 
(LeSueur 1821) population for years 1973-1977. International Commission for the Northwest Atlantic fisheries, Report No 5364.

Lordan, C., Burnell, G.M., Cross, T.F., 1998. The diet and ecological importance of Illex coindetii and Todaropsis eblanae (Cephalopoda: Ommastrephidae) in Irish waters. S. Afr. J. Marine Sci. 20, 153-163.

Lordan, C., Casey, J., 1999. The first evidence of offshore spawning in the squid species Loligo forbesi. J. Mar. Biol. Assoc. U.K. 79, 379-381.

Lum-Kong, A., Pierce, G.J., Yau, C., 1992. Timing of spawning and recruitment in Loligo forbesi Steenstrup (Cephalopoda: Loliginidae) in Scottish waters. J. Mar. Biol. Assoc. U.K. 72, 301-311.

Martin, M., Osborn, K.E., Billig, P., Glickstein, N., 1981. Toxicities of ten metals to Crassostrea gigas and Mytilus edulis embryos and Cancer magister larvae. Mar. Pollut. Bull. 12, 183-188.

Miramand, P., Bentley, D., 1992. Concentration and distribution of heavy metals in tissues of two cephalopods, Eledone cirrhosa and Sepia officinalis, from the French coast of the English Channel. Mar. Biol. 114, 407-414.

Miramand, P., Bustamante, P., Bentley, D., Kouéta, N., 2006. Variation of heavy metal concentrations ( $\mathrm{Ag}, \mathrm{Cd}, \mathrm{Co}, \mathrm{Cu}, \mathrm{Fe}, \mathrm{Pb}, \mathrm{V}, \mathrm{Zn}$ ) during the life cycle of the common cuttlefish Sepia officinalis. Sci. Total Environ. 361, 132-143.

Miramand, P., Guary, J.C., Fowler, S.W., 1980. Vanadium transfer in the mussel Mytilus galloprovincialis. Mar. Biol. 56, 281-293.

Monteiro, L.R., Porteiro, F.M., Gonçalves, J.M., 1992. Inter- and intra-specific variation of mercury levels in muscle of cephalopods from the Azores. Arquipelago 10, 13-22.

Nesis, K., 1987. Cephalopods of the world: squid, cuttlefishes, octopuses and allies. TFH Publications, Neptune City.

Nieboer, E.E., Richardson, D.H.S., 1980. The replacement of the nondescript term 'heavy metals' by a biologically and chemically significant classification of metal ions. Environ. Pollut. 1, 3-26

Pierce, G.J., Bailey, N., Stratoudakis, Y., Newton, A., 1998. Distribution and abundance of the fished population of Loligo forbesi in Scottish waters: analysis of research cruise data. ICES J. Mar. Sci. 55, 14-33.

Pierce, G.J., Boyle, P.R., Hastie, L.C., Key, L., 1994a. The life history of Loligo forbesi (Cephalopoda: Loliginidae) in Scottish waters. Fish. Res. 21, 17-41. 
Pierce, G.J., Boyle, P.R., Hastie, L.C., Santos, M.B., 1994c. Diets of squid Loligo forbesi and Loligo vulgaris in the northeast Atlantic. Fish. Res. 21, 149-164.

Pierce, G.J., Boyle, P.R., Hastie, L.C., Shanks, A.M., 1994b. Distribution and abundance of the fished population of Loligo forbesi in UK waters: analysis of fishery data. Fish. Res. 21, 193-216.

Pierce GJ, Santos MB., 1996. Trophic interactions of squid Loligo forbesi in Scottish waters. In: Greenstreet, S.P.R., Tasker, M.L. (Ed.), Aquatic Predators and their Prey. Fishing News Books, Oxford, pp. 58-64.

Pierce, G.J., Zuur, A.F., Smith, J.M., Santos, M.B., Bailey, N., Chen, C.-S., Boyle, P.R., 2005. Interannual variation in life-cycle characteristics of the veined squid (Loligo forbesi) in Scottish (UK) waters. Aquat. Living Resour. 18, 327-340.

Quetglas, A., Alemany, F., Carbonell, A., Merella, P., Sanchez, P., 1999. Diet of the European flying squid Todarodes sagittatus (Cephalopoda: Ommastrephidae) in the Balearic Sea (western Mediterranean). J. Mar. Biol. Assoc. U.K. 79, 479-486.

Rainbow, P.S., 1989. Copper, cadmium and zinc concentrations in oceanic amphipod and euphausiid crustaceans, as a source of heavy metals to pelagic seabirds. Mar. Biol. $103,513-518$.

Roper, C.F.E., Sweeney, M.J., Nauen, C.E., 1984. Cephalopods of the world. An annotated and illustrated catalogue of species of interest to fisheries. FAO Fisheries Synopsis, no 125, vol. 3 .

Rossi, A., Pellegrini, D., Belcari, P., Barghigiani, C., 1993. Mercury in Eledone cirrhosa from the Northern Tyrrhenian Sea: contents and relations with life cycle. Mar. Pollut. Bull. 26, 683-686.

Salman, A., Laptikhovsky, V., 2002. First occurrence of egg masses of Loligo forbesi (Cephalopoda: Loliginidae) in deep waters of the Aegean Sea. J. Mar. Biol. Assoc. U.K. 82, 925-926.

Santos, M.B., Pierce, G.J., Herman, J., Lopez, A., Guerra, A., Mente, E., Clarke, M.R., 2001. Feeding ecology of Cuvier's beaked whale (Ziphius cavirostris): a review with new information on the diet of this species. J. Mar. Biol. Assoc. U.K. 81, 687-694.

Seixas, S., Bustamante, P., Pierce, G.J., 2005. Accumulation of mercury in the tissues of the common octopus Octopus vulgaris (L.) in two localities on the Portuguese coast. The Sci. Total Environ. 340, 113-122.

Shaw, R., 1994. An economic description and assessment of the squid catching industry in the UK, Portugal and Spain. Fish. Res. 21, 287-304. 
Sims, D.W., Genner, M.J., Southward, A.J., Hawkins, S.J., 2001. Timing of squid migration reflects North Atlantic climate variability. P. Roy. Soc. Lond. B Bio. 268, 2607-2611.

Smale, M.J., 1996. Cephalopods as prey. IV. Fishes. Phil. Trans. R. Soc. Lond. B. 351, 10671081.

Storelli, M.M., Barone, G., Marcotrigiano, G.O., 2005. Cadmium in cephalopod molluscs: implications for public health. J. Food Protect. 68, 577-580.

Storelli, M.M., Giacominelli-Stuffler, R., Storelli, A., Marcotrigiano, G.O., 2006. Cadmium and mercury in cephalopod molluscs: estimated weekly intake. Food Addit. Contam. $23,25-30$.

Storelli, M.M., Marcotrigiano G.O., 1999. Cadmium and total mercury in some cephalopods from the South Adriatic Sea (Italy). Food Addit. Contam. 16, 261-265.

Tanaka T., Hayashi Y., Ishizawa M., 1983. Subcellular distribution and binding of heavy metals in the untreated liver of the squid; comparison with data from the livers of cadmium and silver exposed rats. Experientia 39, 746-748.

Villanueva, R., Bustamante P., 2006. Composition in essential and non-essential elements of early stages of cephalopods and dietary effects on the elemental profiles of Octopus vulgaris paralarvae. Aquaculture 261, 225-240.

Warnau, M., Iaccarino, M., De Biase, A., Temara, A., Jangoux, M., Dubois, P.H., Pagano, G., 1996. Spermiotoxicity and embryotoxicity of heavy metals in the echinoid Paracentrotus lividus. Environ. Toxicol. Chem. 15, 1931-1936.

WHO, 1989. Toxicological evaluation of certain food additives and contaminants. WHO Food Additives Series 24. Geneva.

WHO, 1992. Cadmium - environmental aspects. Environmental Health Criteria. 135. World Health Organization, Geneva

WHO, 2003. WHO, Joint FAO/WHO Expert Committee on Food Additives and Contaminants, Sixty-first meeting. Summary and conclusions (2003) Published at the Web at: ftp://ftp.fao.org/es/esn/jecfa/jefca61sc.pdf. 22 pp.

Zauke, G.P., Petri, G., 1993. Metal concentrations in Antarctic crustacean: the problem of background levels. In: Dallinger R, Rainbow PS (eds) Ecotoxicology of metals in Invertebrates. Lewis publishers, London, pp 73-101 


\section{Caption to figures}

Figure 1. Smoothers for effects of dorsal mantle length (DML) on (a) cadmium (Cd) and (b) mercury ( $\mathrm{Hg}$ ) concentrations $\left(\mu \mathrm{g} \cdot \mathrm{g}^{-1} \mathrm{dwt}\right)$ in the digestive gland of Loligo forbesi. The y-axis shows the contribution of the smoother to the predictor function (in arbitrary units). Smoothers illustrate the partial effect of DML, i.e. the effect of DML once the effects of all other explanatory variables in the model have been taken into account. Dashed lines represent 95\% confidence bands for the smoothers.

Figure 2. Cadmium $(\mathrm{Cd})$ and mercury $(\mathrm{Hg})$ concentrations $\left(\mu \mathrm{g} \cdot \mathrm{g}^{-1} \mathrm{dwt}\right)$ in tissues of L. forbesi for areas sampled. CNS = Central North Sea, EC = English Channel, IS = Irish Sea, IW = Irish West Coast, MF = Moray Firth, NSUK = North Sea Coast UK, SWC $=$ Scottish West Coast. 
Figure 1.

(a)

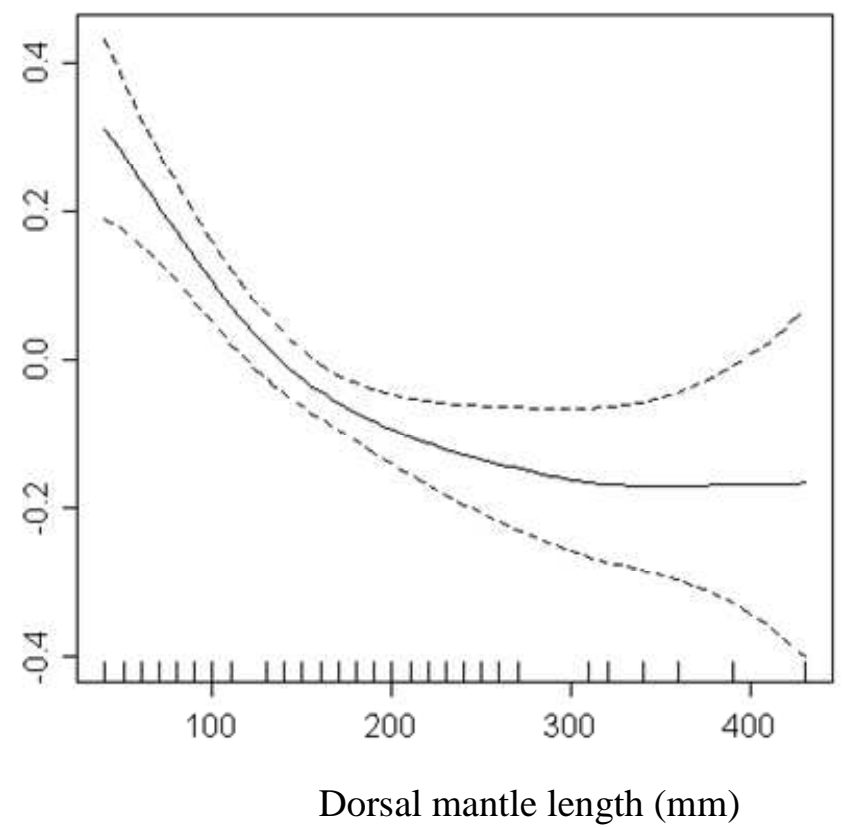

(b)

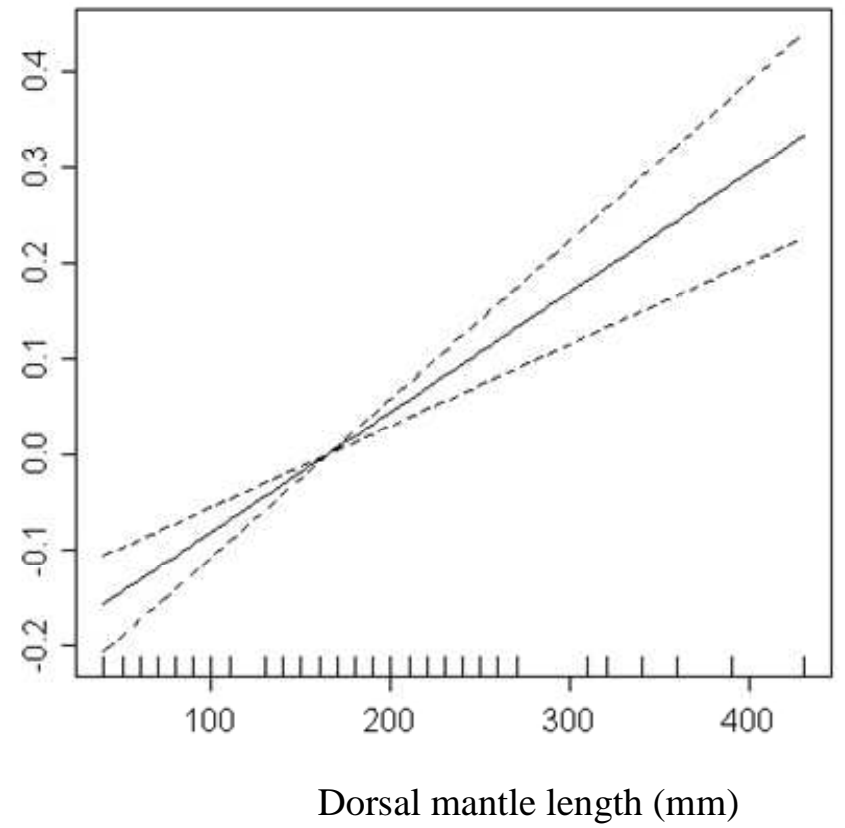


Figure 2

Digestive gland

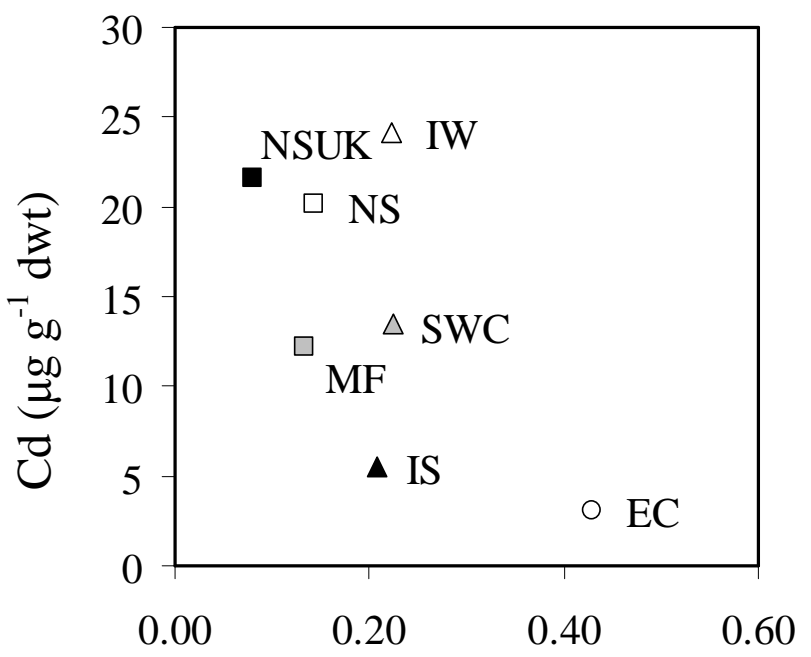

$\mathrm{Hg}\left(\mu \mathrm{g} \mathrm{g}^{-1} \mathrm{dwt}\right)$

Gills

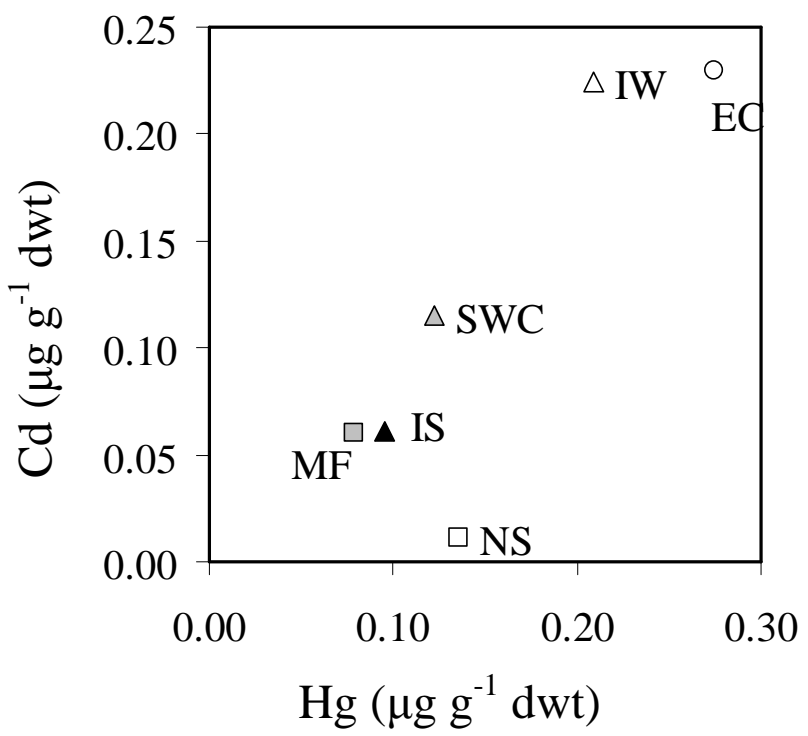

Muscle

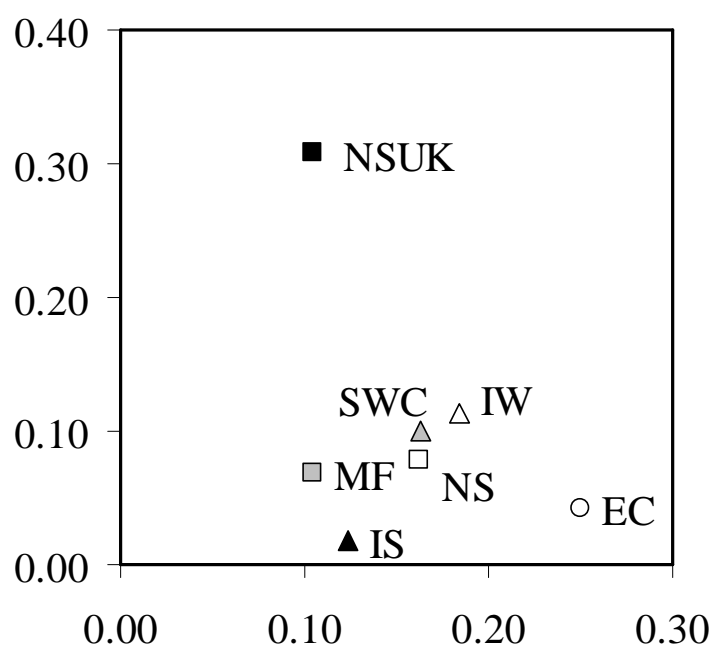

$\mathrm{Hg}\left(\mu \mathrm{g} \mathrm{g}^{-1} \mathrm{dwt}\right)$

Gonads

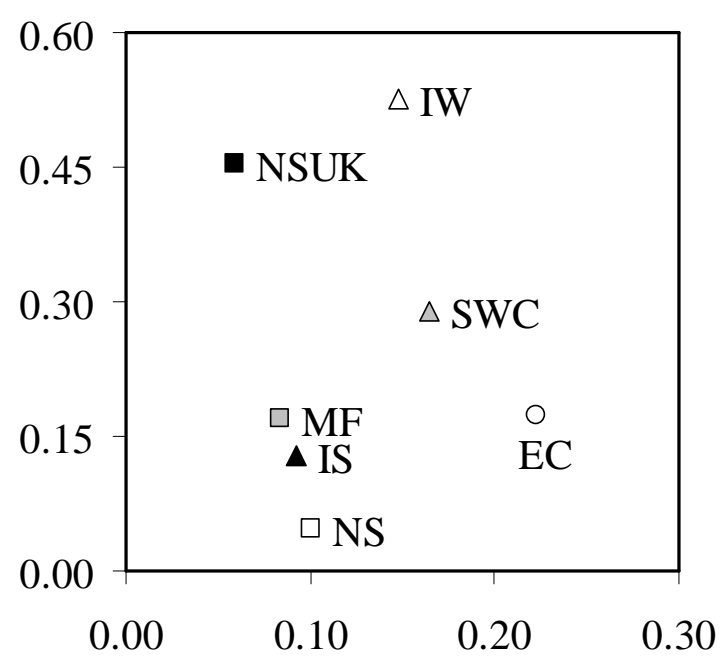

$\mathrm{Hg}\left(\mu \mathrm{g} \mathrm{g}^{-1} \mathrm{dwt}\right)$ 
Table 1. Size and maturity in sampled L. forbesi, grouped according to sex, for each quarter of the year. For dorsal mantle length (DML), the table shows the mean \pm 1 standard deviation. For maturity, the range and median values for the maturity stage index are given. The proportion of mature squids refers to stages 4 and 5 .

\begin{tabular}{|c|c|c|c|c|c|c|c|c|}
\hline \multirow[b]{2}{*}{ Season/year } & \multicolumn{4}{|c|}{ Males } & \multicolumn{4}{|c|}{ Females } \\
\hline & $\mathrm{n}$ & $\mathrm{DML}(\mathrm{mm})$ & Maturity & $\begin{array}{c}\text { Proportion of } \\
\text { mature squids }(\%)\end{array}$ & $\mathrm{n}$ & $\mathrm{DML}(\mathrm{mm})$ & Maturity & $\begin{array}{c}\text { Proportion of } \\
\text { mature squids }(\%)\end{array}$ \\
\hline Spring 04 & 136 & $105 \pm 87$ & $1-5(1)$ & 18 & 119 & $106 \pm 66$ & $1-5(2)$ & 24 \\
\hline Summer 04 & 171 & $128 \pm 57$ & $1-3(2)$ & 0 & 131 & $110 \pm 42$ & $1-4(1)$ & 5 \\
\hline Autumn 04 & 256 & $161 \pm 93$ & $1-5(3)$ & 32 & 232 & $156 \pm 54$ & $1-4(3)$ & 8 \\
\hline Winter 05 & 20 & $241 \pm 72$ & $2-5(4)$ & 65 & 18 & $203 \pm 43$ & $1-5(4)$ & 67 \\
\hline Spring 05 & 77 & $150 \pm 69$ & $1-5(4)$ & 51 & 51 & $169 \pm 65$ & $1-5(4)$ & 67 \\
\hline
\end{tabular}


Table 2. Concentrations of $\mathrm{Cd}$ and $\mathrm{Hg}$ (mean \pm 1 standard deviation) in the tissues analyzed for all species. Also shown are the mean mantle length $(\mathrm{mm}, \pm 1$ standard deviation) and the maximum safe weekly consumption (MSWC) (kg) of each tissue of each species. The MSWC is the weight of cephalopod tissue that must be consumed, assuming $100 \%$ assimilation, to reach the PTWI $\left(7 \mu \mathrm{g} \mathrm{Cd} \cdot \mathrm{kg}^{-1} \cdot \mathrm{wk}^{-1}\right.$ and $\left.5 \mu \mathrm{g} \mathrm{Hg} \cdot \mathrm{kg}^{-1} \cdot \mathrm{wk}^{-1}\right)$ for an average person of $60 \mathrm{~kg}$ body weight.

\begin{tabular}{|c|c|c|c|c|c|c|c|}
\hline \multirow[t]{2}{*}{ Species and tissues } & \multirow[t]{2}{*}{$\mathrm{N}$} & \multicolumn{2}{|c|}{ Cd concentration } & \multirow{2}{*}{$\begin{array}{c}\text { MSWC } \\
(\mathrm{kg})\end{array}$} & \multicolumn{2}{|c|}{$\mathrm{Hg}$ concentration } & \multirow{2}{*}{$\begin{array}{c}\text { MSWC } \\
(\mathrm{kg})\end{array}$} \\
\hline & & $\mu \mathrm{g} \cdot \mathrm{g}^{-1} \mathrm{dwt}$ & $\mu \mathrm{g} \cdot \mathrm{g}^{-1} \mathrm{wwt}$ & & $\mu \mathrm{g} \cdot \mathrm{g}^{-1} \mathrm{dwt}$ & $\mu \mathrm{g} \cdot \mathrm{g}^{-1} \mathrm{wwt}$ & \\
\hline \multicolumn{8}{|l|}{ Loliginidae } \\
\hline \multicolumn{8}{|l|}{ Loligo forbesi } \\
\hline Digestive gland & 105 & $12.2 \pm 9.92$ & $3.31 \pm 2.31$ & 0.127 & $0.216 \pm 0.176$ & $0.065 \pm 0.052$ & 4.6 \\
\hline Muscle & 101 & $0.093 \pm 0.146$ & $0.021 \pm 0.033$ & 20.0 & $0.153 \pm 0.081$ & $0.035 \pm 0.019$ & 8.6 \\
\hline Gonads & 47 & $0.116 \pm 0.160$ & $0.028 \pm 0.036$ & 15.0 & $0.140 \pm 0.090$ & $0.034 \pm 0.022$ & 8.8 \\
\hline Gills & 78 & $0.245 \pm 0.318$ & $0.055 \pm 0.066$ & 7.6 & $0.128 \pm 0.083$ & $0.029 \pm 0.019$ & 10.3 \\
\hline Remaining tissues & 77 & $0.533 \pm 0.639$ & $0.110 \pm 0.121$ & 3.8 & $0.129 \pm 0.067$ & $0.028 \pm 0.015$ & 10.7 \\
\hline \multicolumn{8}{|l|}{ Alloteuthis sp. } \\
\hline Digestive gland & 5 & $9.48 \pm 2.30$ & $2.27 \pm 0.62$ & 0.185 & $0.072 \pm 0.011$ & $0.017 \pm 0.002$ & 17.6 \\
\hline Muscle & 20 & $0.797 \pm 0.204$ & $0.159 \pm 0.033$ & 2.6 & $0.098 \pm 0.011$ & $0.017 \pm 0.005$ & 17.6 \\
\hline \multicolumn{8}{|c|}{ Ommastrephidae } \\
\hline \multicolumn{8}{|l|}{ Todaropsis eblanae } \\
\hline Digestive gland & 23 & $25.1 \pm 25.9$ & $8.41 \pm 8.64$ & 0.050 & $0.128 \pm 0.099$ & $0.042 \pm 0.031$ & 7.1 \\
\hline Muscle & 23 & $1.55 \pm 2.15$ & $0.256 \pm 0.311$ & 1.6 & $0.206 \pm 0.201$ & $0.035 \pm 0.035$ & 8.6 \\
\hline Gonads & 4 & $0.600 \pm 0.871$ & $0.143 \pm 0.211$ & 2.9 & $0.162 \pm 0.109$ & $0.039 \pm 0.026$ & 7.7 \\
\hline Gills & 6 & $5.69 \pm 5.09$ & $1.23 \pm 1.10$ & 0.341 & $0.187 \pm 0.133$ & $0.041 \pm 0.030$ & 7.3 \\
\hline Remaining tissues & 6 & $1.20 \pm 1.30$ & $0.238 \pm 0.218$ & 1.8 & $0.169 \pm 0.143$ & $0.029 \pm 0.022$ & 10.3 \\
\hline \multicolumn{8}{|l|}{ Todarodes sagittatus } \\
\hline Digestive gland & 11 & $65.3 \pm 61.1$ & $30.7 \pm 27.5$ & 0.015 & $0.280 \pm 0.105$ & $0.110 \pm 0.066$ & 2.7 \\
\hline Muscle & 12 & $0.304 \pm 0.292$ & $0.068 \pm 0.065$ & 6.2 & $0.425 \pm 0.194$ & $0.080 \pm 0.054$ & 3.8 \\
\hline Gonads & 6 & $1.00 \pm 1.37$ & $0.211 \pm 0.289$ & 2.0 & $0.286 \pm 0.106$ & $0.061 \pm 0.026$ & 4.9 \\
\hline Gills & 7 & $8.67 \pm 8.98$ & $1.68 \pm 1.63$ & 0.250 & $0.245 \pm 0.136$ & $0.047 \pm 0.036$ & 6.4 \\
\hline Remaining tissues & 7 & $1.41 \pm 1.56$ & $0.305 \pm 0.356$ & 1.4 & $0.289 \pm 0.146$ & $0.064 \pm 0.034$ & 4.7 \\
\hline
\end{tabular}


Table 3. Concentrations of $\mathrm{Cd}$ and $\mathrm{Hg}$ (mean $\pm 1 \mathrm{SD} \mu \mathrm{g} \cdot \mathrm{g}^{-1} \mathrm{dwt}$ ), by area and month, in tissues of L. forbesi. No gonad tissue was analysed for samples from the Irish West Coast.

\begin{tabular}{|c|c|c|c|c|}
\hline \multirow{2}{*}{$\begin{array}{l}\text { Area / tissue sampled } \\
\text { Moray Firth }\end{array}$} & \multicolumn{2}{|c|}{$\mathrm{Cd}$} & \multicolumn{2}{|c|}{$\mathrm{Hg}$} \\
\hline & January & August & January & August \\
\hline Digestive gland & $9.14 \pm 3.57$ & $14.9 \pm 3.7$ & $0.192 \pm 0.063$ & $0.081 \pm 0.012$ \\
\hline Muscle & $0.048 \pm 0.029$ & $0.085 \pm 0.058$ & $0.120 \pm 0.019$ & $0.091 \pm 0.009$ \\
\hline Gills & $0.099 \pm 0.086$ & $0.204 \pm 0.195$ & $0.138 \pm 0.043$ & $0.057 \pm 0.014$ \\
\hline Gonad & $0.077 \pm 0.090$ & $0.026 \pm 0.009$ & $0.087 \pm 0.029$ & $0.064 \pm 0.010$ \\
\hline Scottish West Coast & March & November & March & November \\
\hline Digestive gland & $28.8 \pm 19.0$ & $11.9 \pm 10.3$ & $0.314 \pm 0.054$ & $0.126 \pm 0.080$ \\
\hline Muscle & $0.144 \pm 0.117$ & $0.099 \pm 0.147$ & $0.281 \pm 0.081$ & $0.107 \pm 0.035$ \\
\hline Gills & $0.543 \pm 0.448$ & $0.337 \pm 0.460$ & $0.225 \pm 0.054$ & $0.094 \pm 0.048$ \\
\hline Gonad & $0.290 \pm 0.160$ & $0.083 \pm 0.119$ & $0.202 \pm 0.032$ & $0.095 \pm 0.034$ \\
\hline Irish West Coast & April & November & April & November \\
\hline Digestive gland & $18.1 \pm 2.94$ & $30.2 \pm 8.18$ & $0.363 \pm 0.265$ & $0.081 \pm 0.014$ \\
\hline Muscle & $0.065 \pm 0.038$ & $0.162 \pm 0.167$ & $0.270 \pm 0.038$ & $0.098 \pm 0.053$ \\
\hline Gills & $0.121 \pm 0.060$ & $0.930 \pm 0.563$ & $0.221 \pm 0.052$ & $0.074 \pm 0.039$ \\
\hline
\end{tabular}

